\title{
Kernos
}

Revue internationale et pluridisciplinaire de religion grecque antique

$2 \mid 1989$

Varia

\section{The Cult of Erechtheus and Athena on the Acropolis of Athens}

\section{Nicolaos Papachatzis}

\section{OpenEdition \\ Journals}

\section{Electronic version}

URL: http://journals.openedition.org/kernos/247

DOI: $10.4000 /$ kernos. 247

ISSN: 2034-7871

\section{Publisher}

Centre international d'étude de la religion grecque antique

\section{Printed version}

Date of publication: 1 January 1989

Number of pages: 175-185

ISSN: 0776-3824

\section{Electronic reference}

Nicolaos Papachatzis, "The Cult of Erechtheus and Athena on the Acropolis of Athens », Kernos

[Online], 2 | 1989, Online since 02 March 2011, connection on 01 May 2019. URL : http://

journals.openedition.org/kernos/247; DOI : 10.4000/kernos.247 
Kernos, 2 (1989), p. 175-185.

\section{THE CULT OF ERECHTHEUS AND ATHENA ON THE ACROPOLIS OF ATHENS}

The common cult of Erechtheus and Athena on the Acropolis was recognized by the ancients as the oldest and most venerable of all Athenian cults. A clear reference to this cult is made by Plutarch (Sympos. Probl., 9, 6) :

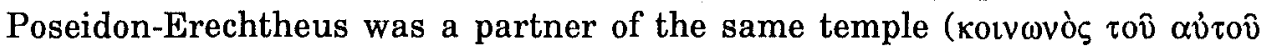
v $\alpha 0 \hat{v}$ ) with Athena (Fig. 1). Erechtheus and Athena were pre-Olympian deities of Attica.

\section{Chthonic Poseidon and kindred local gods}

Erechtheus was an $\varepsilon^{\prime} \varepsilon^{\prime} \chi \theta \omega v$ god $^{1}$ who rends or breaks the earth, an earth-

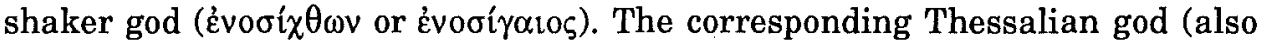

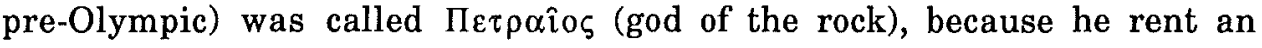
enormous rock at Tempe and created the famous channel of the river

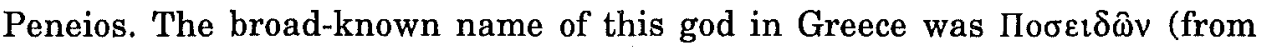
oldest times perhaps in Arcadia), to whom the Thessalians identified their

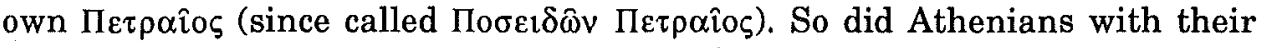

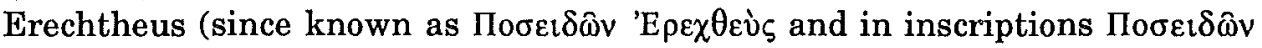

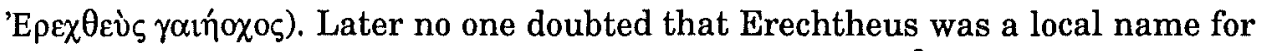

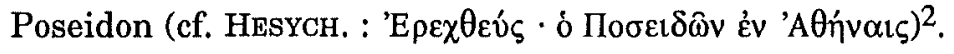

\section{The goddess Athena}

Athena, the associate of Erechtheus in worship, was not his wife, as one would expect; in myths very early she appeared as a young virgin goddess, and it was impossible to become the wife of an aged god. Otherwise, the idea that she could be a daughter of Poseidon-Erechtheus can not find any support in the Athenian myths ${ }^{3}$.

1 The verb غ́péx $\theta \omega$, very common in Homer, means to rend, to disturb, to shake violently.

2 In this early age it is obvious that Poseidon was a chthonic god, like Erechtheus, without any direct relation to the sea. (Athenians had for the sea a local daemon

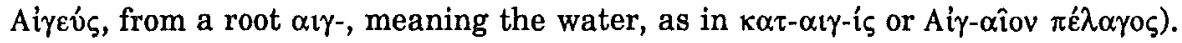

3 According to a Libyan myth mentioned by Herodotus $(4,180)$, Athena's real father was Poseidon and mother the nymph of the lake Tritonis. After a conflict with Poseidon, Athena abandoned him and recognized Zeus as her father. It is self-evident 
The fact of co-existence in the same sanctuary of a god and a goddess, who had no relationship by marriage and did not have also any other nearness of kin, could perhaps find a plausible explanation by assuming that they were two separate favoured deities of two different groups of inhabitants resided near the Acropolis. If the two groups had agreed to live in peace, they should have decided at the same time to establish a common sanctuary of their deities on the Acropolis.

Herodotus often mentions sections or troops of Pelasgians settled round Acropolis not only during remote prehistoric years, but also later, in the dawn of the historic period $(1,57)$. Pelasgians were numerous in Attica. The people

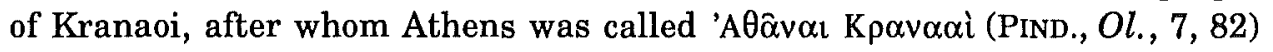
were Pelasgians, according to Herodotus $(8,44)$. Ionians also, expelled by Achaians from Peloponnesos, were established in Attica and Boeotia, before their migration to Asia Minor. The large group of Cecropidae, after which Attica was called Cecropia for a while, had also settled in the vicinity of Acropolis. Each group was constantly engaged in struggles with neighbours to protect its land and its goods, but also to impose its favourite god or goddess to its rivals. Mythmaking poets later spoke about the strife of the gods for the "possession of the land". The most important strife was the famous contest between Poseidon and Athena, which took place during the highest opposition of the old chthonic and the new Olympian gods (i.e. during the so-called dark ages, from 1150 to 900 B.C.). Chthonic Poseidon was then defeated, because his rival was already one of the prominent Olympians. The young Athena was among the first chthonic deities who abandoned the chthonic Pantheon and entered the Olympian one. Her chthonic substance survived only in popular cults (as was her cult in Erechtheum too).

\section{Goddess Athena as Polias and as Parthenos or Promachos}

With Athena as Olympian or celestial goddess (always of bellicose type) a new era of religious life began in Athens.

Already in the second half of the sixth century B.C. the Olympian Athena started to throw her shade on Polias, the old and venerable protectress of the city. She took possession of Acropolis with the surnames Parthenos and Promachos, while the goddess of the forefathers maintained her old epithet Polias and a humble mystic worship with Erechtheus.

In the fifth century, Athena Polias and Athena Parthenos became two separate goddesses with different features, although the Athenians wished to

that her opposition to Poseidon was due to the fact that she changed herself into an Olympian goddess very early, while Poseidon continued to be a chthonic god. 
see their familiar Athena in both of them. Parthenos Athena became the brilliant official goddess of the state, with the Parthenon as her temple and the pompous Great Panathenaea as her main feast. Distinguished citizens entrusted their ambition for supremacy over Greece to her. Her statue in the Parthenon, the famous «chryselephantine Athena», wrought by Pheidias, was 12 meters in height and had garments and weapons of gold of a net weight of 40 talents, i.e. more than one ton. Her second statue on the Acropolis, the so-called Athena Promachos, made of bronze, was 9 meters tall : it was raised in the open air, immediately after entering the Propylaea and it gave the impression that this was the goddess who commanded the Acropolis. Nevertheless piety is fostered neither by the greatness in size nor by the richness in gold : so it is evident that both statues addressed rather to the artistic feeling than to piety. Fine arts, from classic period on, started an autonomous development, often harmful to the religion. The cult of Athena Parthenos was showy, not pious.

On the contrary, Athena Polias with her familiar chthonic peculiarities, survived as a humble vegetation goddess with fertility rites. PoseidonErechtheus, with whom she shared the worship, was a kindred deity, especially with the epithet $\varphi v \tau \alpha \dot{\alpha} \lambda \mu{ }_{10}$ (producing or nourishing the plants) ${ }^{4}$.

Polias Athena had no impressive images. Her famous statue was made of olive wood and stood in her "old temple" (later in the Erechtheum); some said

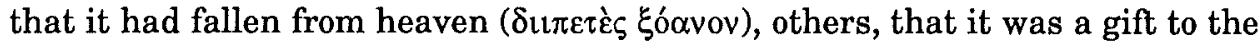
goddess by Cecrops, the forefather of the Athenians. it was a small xoanon, light to bear, and represented the goddess seated on a throne, at least the older one, which existed in the "old temple», before the destruction of the Acropolis in 480 B.C. 5 .

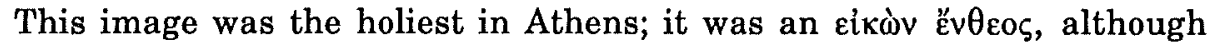

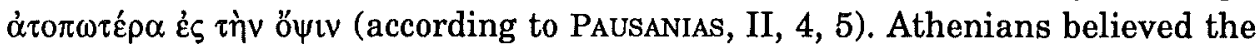
city was under its protection, day and night. In the feast of Plynteria, when the statue was carried to the sea, and the temple was left without its image, no

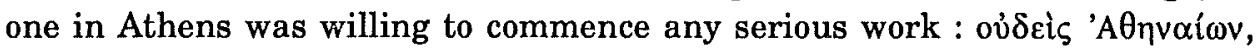

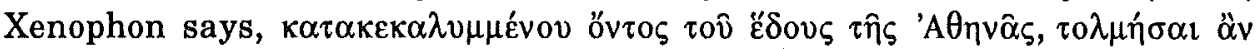

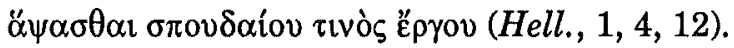

4 Poseidon, the ruler or master of the sea, was another god : he had already become a shining personality of mythology, without any warm cult (many sea-deities existed besides him).

5 Homer does not know any other image of Athena, except the seated one (Il., VI, 303). Seated was represented especially the queen of the nether world. The same image was the appropriate one for the primitive xoanon of the chthonic Athena. After 480 B.C. perhaps the older statue was replaced by another image, again wooden, for which we do not know whether it represented the goddess seated or upright. 
An olive-oil lamp was constantly burning in front of this statue, day and night, all year long (ö $\left.\sigma \beta \varepsilon \sigma \tau o \varsigma \quad \lambda \dot{\chi} \chi \sigma_{0 \varsigma}\right)$. With this eternal lighting the Athenians paid their continuous respect to Athena Polias.

\section{The cults in the Erechtheum}

Prehistoric cult places occupied especially the north section of the hill surface, i.e. the area of the classic Erechtheum, between this building and the north leg of the pelasgic wall. Excavations uncovered traces of open-air sanctuaries, of enclosures with altars, as well as small chapels $(\mu \varepsilon \dot{\varepsilon} \gamma \alpha \rho \alpha$ or $\alpha \delta^{\prime} v \tau \alpha$ ) for chthonic rites (Fig. 2).

Herodotus, who visited Acropolis about the middle of the fifth century B.C. and before the erection of the periclean monumental temples, saw at the north

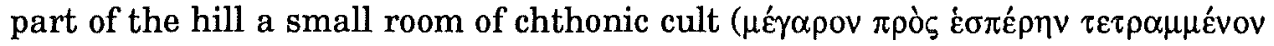
5,78 ); in this adyton or in another of the same kind some Athenians took refuge in 480 B.C. and within the adyton they were killed by the Persians

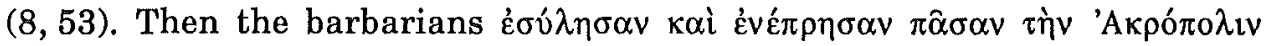
(same passage). Among the burnt sanctuaries was also the most important one of the north district of the hill, which was called by the Athenians of the

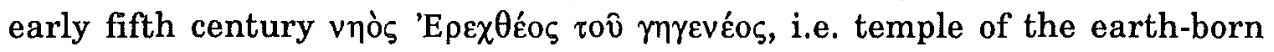

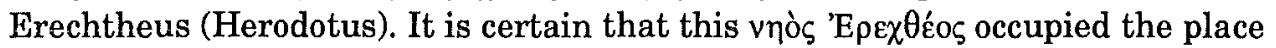
of the afterwards Erechtheum, because included, as Herodotus adds, the famous tokens of the contest of Athena with Poseidon, i.e. the trident mark, the well of salt sea (called 'E $\rho \varepsilon \chi \theta \eta i s \quad \theta \dot{\alpha} \lambda \alpha \sigma \sigma \alpha)$ and the sacred olive-tree of Athena $(8,55)$.

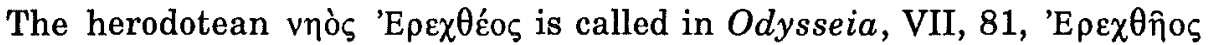

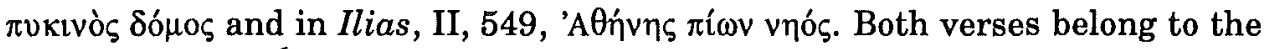
archaic period ${ }^{6}$. It was the period during which the common cult of Erechtheus and Athena flourished on the Acropolis and Athena was praised by poets as the winner of the divine contest. At that prosperous time she became the maiden protectress of the city with the epithet Polias, which inspired a pious awe to every old Athenian. In the next century, when the majestic Parthenos Athena was already regarded as the new protectress of the recently established Athenian empire, many honorable citizens continued to express the previous devotion to Polias Athena, the "Goddess of the ancestors". Plato's devotion is included in the warm words he uses for Polias Athena : "our Maid and Mistress, who dwells among us" (ì $\pi \alpha \rho$ ' $\dot{\eta} \mu \hat{i} v$ Kóp $\eta$

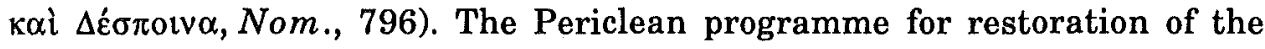

6 DIOG. LAËRTIUS, I, 57, knew that the passage of Ilias, II, 546-556, was composed in the sixth century B.C. and was interpolated into the Ilias by the tyrants. 
Acropolis after the Persian catastrophe contained a second temple, equivalent to the Parthenon in majesty, for the traditional cults of Athens, especially of Athena Polias and Poseidon-Erechtheus. This second temple was the Erechtheum, which, in spite of financial difficulties and war failures, was almost ready at the end of the fifth century.

Athenians honoured their traditional Polias Athena (besides Parthenos)

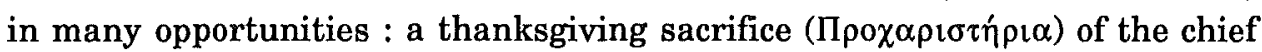
magistrates at the end of the winter (when the new vegetation made its first appearance) was addressed not to Demeter but, according to a local custom (older than the union of Eleusis with Athens), to the chthonic Athena (i.e. to the local vegetation goddess). For the same goddess there was a temple in Phaleron, where Athena was called Skiras (PAus., I, 1, 4). A sanctuary of the same Athena Skiras is mentioned by Herodotus in Salamis also $(8,94)$.

Fertility rites connected with Polias Athena and Erechtheus were practised in the prehistoric years, until the dawn of the historic age and before the 7th century B.C., when Eleusis was united with Athens. After the annexation of Eleusis the cults of Athenian vegetation deities started to decline or were extinguished : the Athenians regarded the Eleusinian deities as their own and took care for the reorganization of the Eleusinian mysteries and for the expansion of the cult. In Eleusis the Athenians replaced a small telesterion of oblong plan with the new rectangular construction, which in the next century became a huge square hall, each side more than 50 meters in length, with 42 inner columns to support the roof. Eight rows of seats at each side were enough for three thousand people. In the second half of 4 th century the building was enlarged by a monumental stoa with twelve columns in front of the entrance.

\section{Survival of some Athenian rites older than the conquest of Eleusis}

Among the old (the pre-Eleusinian) rites were three ritual ploughings

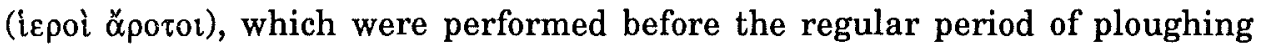
and sowing, in order to reinforce and bless them. One of the ritual ploughings took place in the Eleusinion, on the north foot of the Acropolis. In this sanctuary Pausanias saw a statue of the old Athenian priest Epimenides (not the famous Cretan Epimenides, as Pausanias thought [I, 14, 4]); in connection to this statue was a bronze image of a bull, which Pausanias saw very close to Epimenides. According to an old Athenian tradition,

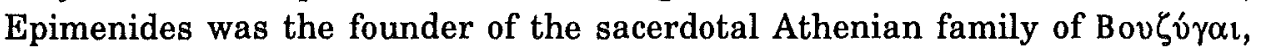
and the first who put to yoke a pair of oxen to draw the plough. The tale was an Athenian one, without any relation to Eleusis. The sanstuary later was 
dedicated to the Eleusinian goddesses and received the name Eleusinion

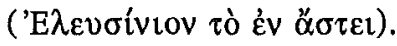

A second ritual ploughing ${ }^{7}$ was connected with the place Skiron in the plain of the Athenian Kephisos. In older years, Athena Polias and Erechtheus were the central deities of the feast of Skira. As a survival must be considered a procession with the priest of Poseidon-Erechtheus and the priestess of Athena Polias which started from the Erechtheum and the Pandroseidon in Acropolis, crossed the Agora and arrived at Skiron for the sacrifice. Later the sanctuary of Skiron was ascribed to Demeter and Kore; even in this later period Athena Polias was honoured with the sacrifice.

Another sanctuary, beyond Skiron, on the same road, belonged to the Eleusinian goddesses; in this sancturay also honors were provided for the two kindred Athenian deities, Athena and Poseidon (Paus., I, 37, 2).

On the Acropolis, the priestess of Athena Polias was responsible for the rites performed in the Pandroseion. The most important among the mystic performances of the Pandroseion were the Arrephoria, which lost their significance after the emergency of the Athenian Thesmophoria and the Eleusinian Mysteries. Pausanias found Arrephoria in decadence (I, 27, 3), because they had remained a simple rustic rite, in opposition to the Eleusinian Mysteries, which promoted an eschatologic teaching reconciling

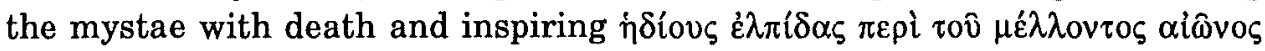
(Isocr., Panyg., 28).

Arrephoria required an absolute secrecy to become successful. Mystic objects and acts had to be hidden to a higher grade than in Thesmophoria and other fertility rites. The ceremony of Arrephoria took its name from the

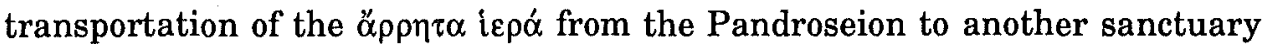
belonging to Aphrodite (which was situated on the north foot of Acropolis). "A $\rho \eta \tau \alpha$ i $\varepsilon \rho \alpha$ were secret objects used as magical charms helping the growth of crops. In the ritual of Arrephoria :

1) the transportation had to be entrusted to persons who had not passed the "age of innocence" (perhaps the age of ignorance too, inasmuch as for the job two young girls were chosen, 7-11 years old).

2) The chosen young girls had to live for a while in the sanctuary of the goddess, far away from any human being.

3) The transportation of the sacred items had to be done during the night, in order to be protected by the darkness.

7 According to Plutarch (Praec. Conj., 42) this ploughing was an $\dot{v} \pi \hat{\jmath} \mu v \eta \mu \alpha$ tôิ

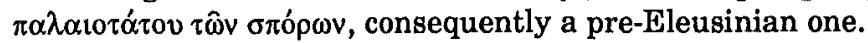


4) The girls, each carrying a basket, had to descend the Acropolis through the rocks, following a secret narrow path, in order to avoid curious eyes (Fig.1).

5) The baskets with the sacred objects were carefully covered, and the girls did not know what exactly they were carrying.

The Hersephoria (which we know from vague information that it took place in the Pandroseion) was another fertility rite, as J.E. Harrison indicated, with the intent to obtain (through a magical process) rain or dew for the plants and vegetables (Themis, 173).

\section{The Erechtheum as a temple}

The Erechtheum was an unusual cult-place. It was destined to embrace, besides the cult of the two older deities of Acropolis, the sacred enclosure of Pandrosos, the venerable grave of Cecrops and the tokens of the contest between Poseidon and Athena. Pre-existent chthonic cults of this kind hindered any free plan of the building and excluded even the attempt of levelling the ground before the construction (for this reason the east and the south walls of the Erechtheum were founded about 3 meters higher than the north and the west ones).

The two impressive entrances of the building (one from the east, with an ionic prostasis of six columns, another from the north, with a higher prostasis of the same number of ionic columns) correspond perhaps to the cult of the two main deities of the "temple», but it is impossible to determine the part belonging to each of them. The east room, which usually is considered as a temple of Polias Athena, was dedicated rather to the cult of PoseidonErechtheus, because Pausanias, coming from the east, first visited this room, within which he saw an altar of Poseidon-Erechtheus, a second one of Hephaestos and a third of Boutes. He did not see any cult-image in the room, and for this reason he calls it oîk $\eta \mu \alpha$ (house or establishment), not $v \alpha$ ò $\zeta$ (temple). On the walls of this oikn $\mu \alpha$ he saw paintings of the sacerdotal family of Eteoboutadae (I, 26, 5). For the paintings abundant light was necessary, and perhaps for this reason two windows (very rare in Greek temples) were left open one on each side of the entrance (exactly as in the pinakothek of the Propylaea, for the paintings there). Three priests were assigned for the cult in this east room. Excavations uncovered two of the inscribed bases of the chairs destined for the two of them (for the priests of Hephaestos and Boutes).

After the tokens of the divine contest, Pausanias mentions the xoanon of Athena Polias and the $\alpha \sigma \beta \varepsilon \sigma \tau \sigma \varsigma \lambda^{u} \chi v \circ \varsigma$ with the vague information that they

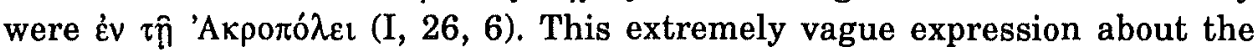
situation of the statue and of the lamp allowed the supposition that they could 
be located within the east room, together with the altars, but the text of

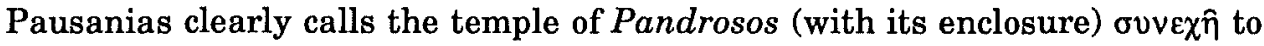

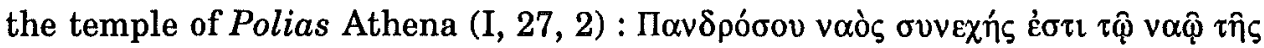
'A $\left.\theta \eta v \alpha \varsigma_{\varsigma}\right)$. So, for Pausanias, the place of Athena's image must have been in the west room of the Erechtheum, which is called by him «temple», because of the presence of the cult-statue.

P. Voutsina 63, Cholargos

Nicolaos PAPACHATZIS GR - 15561 ATHENS 


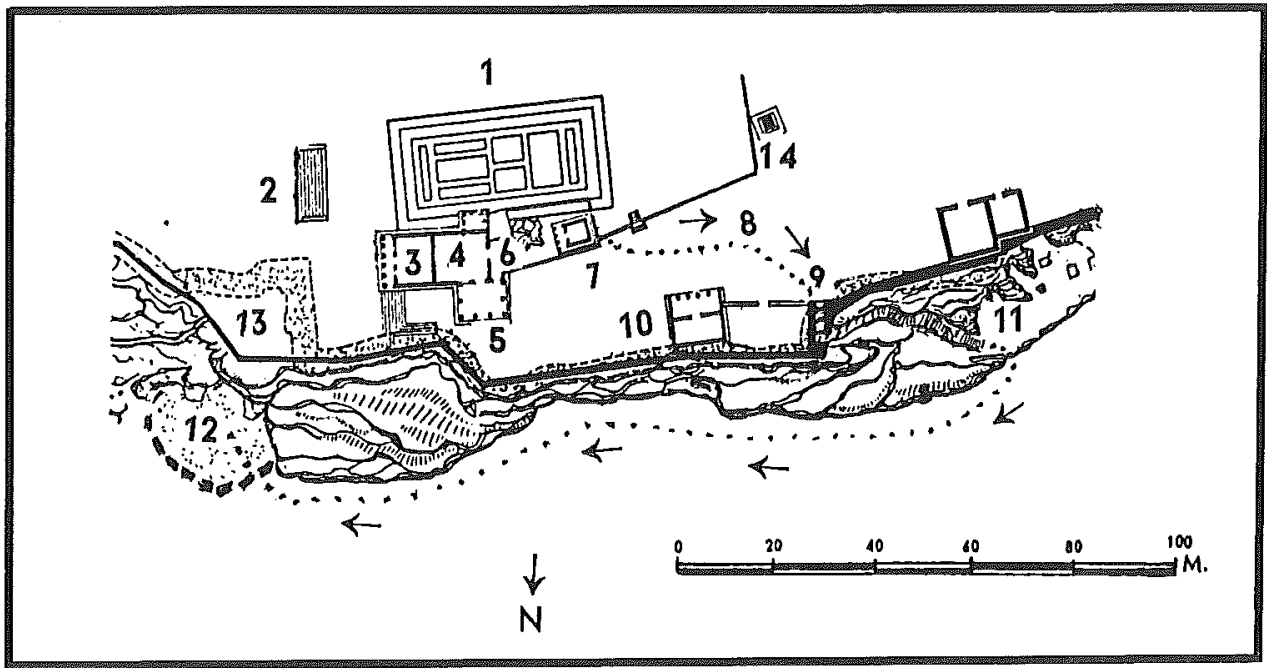

Fig. 1 : The area of the common cult of Poseidon-Erechtheus and Athena Polias.

1. Monumental archaic temple of Athena Polias.

2. The great altar to the same temple.

3. East room of the Erechtheum (less than 7,5 m. in length).

4. The larger west room (more than $10 \mathrm{~m}$. in length).

5. The north porch, from where the west room was accessible.

6. The sanctuary of Pandrosos with her small temple, from where the arrephoroi started descending the Acropolis.

$7,8,9,11,12$. Mystic path followed by the arrephoroi (8-11 secret passage through the rocks).

12. The open-air sanctuary of Aphrodite reached by the arrephoroi during the night.

10. Two rooms used as abode of the arrephoroi (the west one a simple enclosure).

13. Remains of the prehistoric wall ("pelasgicon") of the Acropolis.

14. The place of the great bronze statue of Athena. 


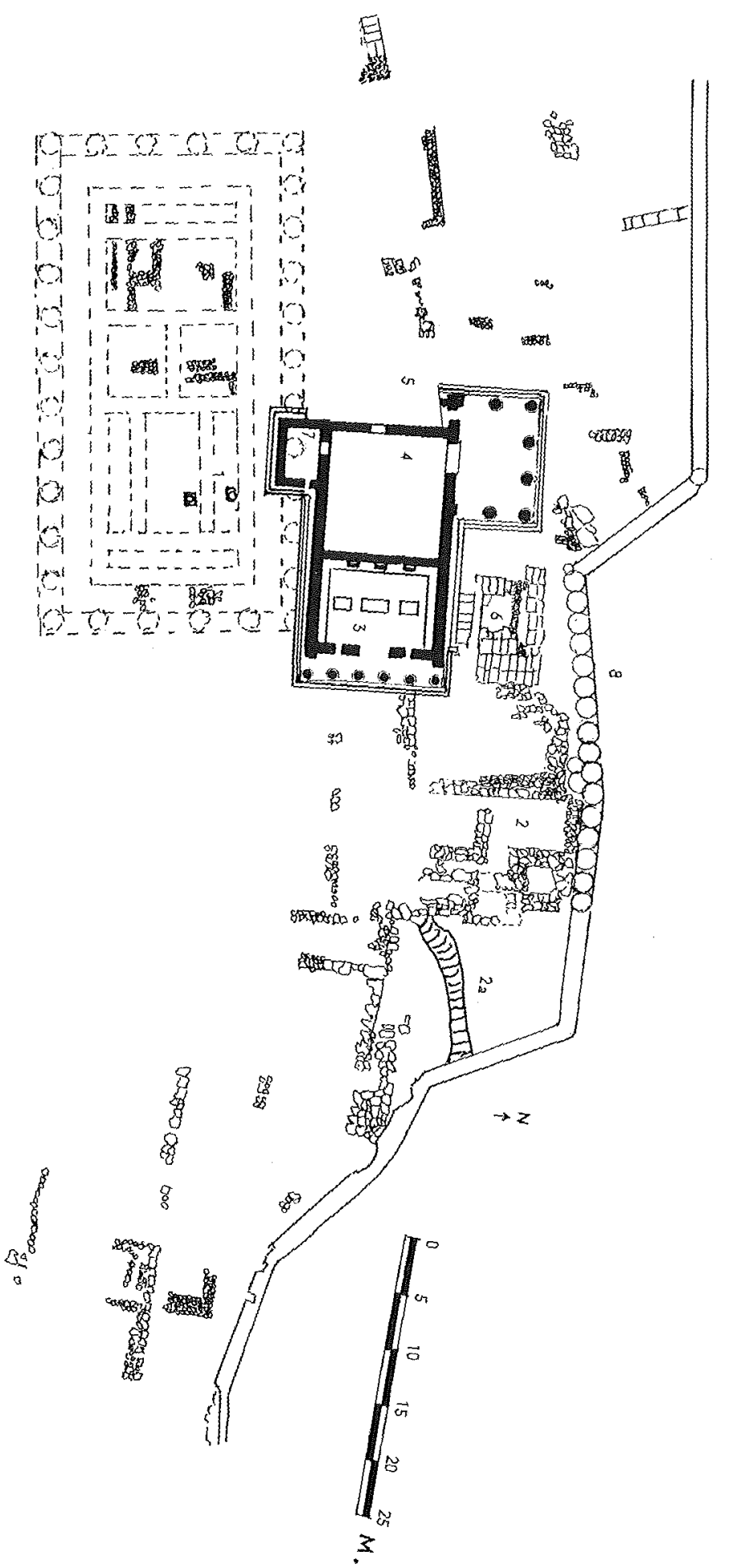




\section{(See opposite page)}

Fig. 2: Prehistoric remains of cult-places and dwellings beneath the archaic temple of Athena and around the classic Erechtheum (drawing based to the plate 7 of AJA, 28 [1924]).

1. Few remains of walls below the foundation of the temple of Athena. The two stone bases of columns (where the number 1) recently are considered not as mycenaean, but as belonging to a temple of the early historic age (Opusc. Atheniensia, 4 [1962], p. 31 ff), at least 130 years older than the archaic temple of Athena.

2. Excavations uncovered more prehistoric walls north-east of the Erechtheum, near the narrow descent (with some steps cut on the rock, Nr. 2a), which ended perhaps to a small door of the Acropolis precinct.

3. The east room or chamber of the Erechtheum was dedicated to the cult of Poseidon-Erechtheus, at least when Pausanias visited and described the building (I, 26, 5). There were within this room : three altars (the main one for Poseidon-Erechtheus, another for Hephaistos and a third for the hero Boutes), three chairs for the three priests and a stone bench in length of the north, west and east sides (for people participating in mystic performances).

4. The larger west room should be dedicated to the cult of Athena Polias.

5. The sanctuary of Pandrosos (the Pandroseion) followed to the west. According to Pausanias (I, 27, 2) it was ujoined together» to the temple of Athena Polias. The small temple of the goddess Pandrosos left no traces.

6. Old cult-place (paved with stones) for an open-air mystic rite.

7. Porch of the maidens, enclosing a part of the venerable grave of Cecrops.

8. North edge of the hill with the wall of the classic period; parts of columnshafts walled in (from temples destroyed by Persians). 